\title{
Intellectual Structure of Mobile Learning Field: Bibliometric Evidence from Turkey (2006-2020)
}

\author{
Beytullah Karagöz \\ Tokat Gaziosmanpaşa University, Tokat, TURKEY \\ Faculty of Education \\ İzzet Şeref \\ Sivas Cumhuriyet University, Sivas, TURKEY \\ Faculty of Education
}

Received: 1 November 2021 - Accepted: 24 December 2021 • Published Online: 30 December 2021

\begin{abstract}
The aim of present study is to examine the intellectual structure of the reference lists of postgraduate theses on mobile learning in Turkey. In this research, 88 postgraduate theses indexed in the National Thesis Center of the Council of Higher Education were examined. According to the obtained findings, it was determined that the most theses were conducted in 2019. The average number of pages and citations of doctoral theses is higher than that of master's theses. The supervisors of the master's theses are mostly Assistant professors while the advisors of doctoral theses are mostly Associate professors and Professors. In both master's and doctoral theses, citations to journal articles are more common. The most cited journals in master's theses were Computers and Education, Turkish Online Journal of Educational Technology, British Journal of Educational Technology. The most cited journals in doctoral theses were Computers and Education and British Journal of Educational Technology. Agnes Kukulska-Hulme and John Traxler's book Mobile Learning: A Handbook for Educators and Trainers is the most cited book in master's theses. Mohamed Ally's book Mobile Learning: Transforming the Delivery of Education and Training comes first in doctoral dissertations. Mike Sharples has been the most cited author in both types of postgraduate theses.
\end{abstract}

Keywords: mobile learning, intellectual structure, citation analysis, research trends.

\section{Introduction}

Today, with the advancement and the significant growth in technology adoption, it has naturally become an integral part of the education. Thus, the education-teaching process has entered a period that can be supported and reorganized with the opportunities provided by technology. This situation has led to an increase in research examining the use of technology in education. Meta-analysis studies examining various studies on the use of technology in education show that the use of technology in education has a positive effect on learning (Bolat \& Göksu, 2020; Cheung \& Slavin, 2012; Dikmen \& Tuncer, 2018; Dinçer, 2015; Shmid, et al., 2014; Tomakin and Yesilyurt, 2013).

(C) Authors. Terms and conditions of Creative Commons Attribution 4.0 International (CC BY 4.0) apply. Correspondence: Beytullah Karagöz, Tokat Gaziosmanpaşa University, Faculty of Education, Tokat, TURKEY. E-mail: beytullah.karagoz@gop.edu.tr. 
B. Karagöz \& İ. Şeref - Intellectual Structure of Mobile Learning Field: Bibliometric Evidence from ...

- The most cited journal in postgraduate theses was Computers and Education.

- Agnes Kukulska-Hulme and John Traxler's book Mobile Learning: A Handbook for Educators and Trainers is the most cited book in master's theses.

- Mohamed Ally's book Mobile Learning: Transforming the Delivery of Education and Training is the most cited book in doctoral dissertations.

- Mike Sharples has been the most cited author in postgraduate theses.

One of the important components of technology adoption in education is mobile learning. Mobile learning has become even more important today with the rapid development of wireless communication and mobile technologies and there has been a tendency towards mobile learning (Chu, Hwang, Tsai, \& Tseng, 2010; Çelik, 2012). Quinn (2001) described mobile learning as e-learning that can be accessed with portable technologies; Özdamar-Keskin (2011) defined it as a learning method that increases the productivity and efficiency of individuals through mobile technologies. The basis of mobile learning consists of learning with portable devices of individuals independent of a particular learning environment. Thanks to mobile technology, students were not obliged to the classroom environment and this technology provided convenience and flexibility for students (Ylldırım, 2012).

Mobile learning, which is predicted to reduce the dependence on time and space, has several advantages. Tanriverdi (2011) categorized the advantages of mobile learning as: place and time flexibility, instant interaction, cheapness, prevalence and ease of transportation of mobile devices, internet infrastructure width (Wi-Fi) and attracting students' attention. In addition to these advantages, mobile learning also has various limitations. These limitations are; connection problems and costs, screen size of mobile devices, data security, system incompatibilities and difficulty in tracking students (Corbeil \& Valdes-Corbeil, 2007; Kantaroğlu \& Akbıyık, 2017).

In the research conducted by Şeylan (2018), it was determined that the effect of mobile learning on academic success was significant in various studies. In addition, in various metaanalysis studies conducted by researchers, it was concluded that the effect size of the contribution of mobile learning to academic success was positive, highly effective and was statistically significant (Guzeller \& Üstünel, 2016; Sönmez \& Çapuk, 2019). In another meta-analysis study the researchers concluded that mobile learning has a positive effect on students' motivation and attitudes as well as academic success (Gür \& Bulut-Özek, 2021).

When the literature is examined, it is seen that there are many studies examining the theses and articles on mobile learning. In Aydoğdu's (2019) study, the methodological dimensions, descriptive features and general tendencies of 47 theses and 180 articles on mobile learning were examined. Göksu (2021) took 5,167 articles as a sample in her study examining the bibliometric map of mobile learning. In the study by Xu, Yang, and Zhu (2018), 2,392 articles indexed in the Web of Science database on mobile learning were handled bibliometrically. Sobral (2020) also evaluated 450 articles scanned in Web of Science and Scopus databases on mobile learning in higher education with bibliometric analysis. Lai (2020) examined the 100 most cited articles in the field in her study on trends in mobile learning. In the study conducted by Uygun and Sönmez (2019), 19 theses and 12 articles were examined in terms of research objectives, method, participant group and data collection instruments. Korucu and Biçer's (2019) study evaluated the descriptive features, methodological dimensions and general trends of a total of 24 articles. In the study conducted by Kavaklı and Near (2019), 44 articles on mobile learning published in three peer-reviewed journals were examined in terms of determining their general trends. In Altunçekiç's (2020) study, 69 articles on mobile learning were discussed in terms of method and descriptive features. 
As can be seen, in recent years, many aspects of theses and articles related to mobile learning have been examined. However, in the literature review, no study was found that reveals the citation characteristics of postgraduate theses prepared in Turkey on mobile learning. In this research, besides the descriptive features of the theses related to mobile learning, the citation features of the theses will also be examined. In this way, the intellectual structure of the mobile learning field will be revealed by determining which authors, which books, which journals and which types of sources are cited most in the theses. It is thought that these findings can provide a broader perspective to the studies in the field and can guide researchers in the mobile learning literature.

This research aims to examine the bibliometric features of the citations of postgraduate theses on mobile learning in Turkey. In addition to this, theses are examined in terms of year, genre, advisor and the title of the advisor. In line with the purpose of the present research, answers to the following questions were sought:

1. What is the distribution of graduate theses by year and type?

2. What is the distribution of the number of pages and citations in graduate theses?

3. How are the titles of the supervisors who directed the postgraduate thesis distributed?

4. What is the distribution of the supervisors who lead the postgraduate thesis?

5. What is the distribution according to the type of source cited in the graduate theses?

6. What are the most cited journals in master's theses?

7. What are the most cited books in master's theses?

8. Who are the most cited authors in master's theses?

9. What are the most cited journals in doctoral theses?

10. What are the most cited books in doctoral theses?

11. Who are the most cited authors in doctoral theses?

2. Material and methods

2.1 Design

The present study was quantitative research and in line with this basic research paradigm, the bibliometric citation analysis technique was also used (Becker \& Chiware, 2015). Thus, the citation analysis of the theses prepared on mobile learning listed in the National Thesis Center of the Council of Higher Education was tried to be done. "Citation analysis is a type of analysis that helps researchers to know the sources that have reached the guiding feature in their fields. The sources, journals and authors that have a decisive role in the literature related to this analysis can be determined" (Karagöz \& Şeref, 2020).

\subsection{Data collection and analysis}

Theses, which are the data source of the research, were obtained from the National Thesis Center of the Council of Higher Education (https://tez.yok.gov.tr/UlusalTezMerkezi/). 
B. Karagöz \& İ. Şeref - Intellectual Structure of Mobile Learning Field: Bibliometric Evidence from ...

Searches were made on 5 January 2021 by choosing the "Advanced Search" tab in the database in question. The searches were carried out with the keywords "mobile learning, mobile, learning, digital, mobile technology, technology" separately, by selecting "all" in the "field to search" section. No limitations were made in the searches, except for keywords. As a result of the search, 109 theses were found. Two of these theses were excluded from the study because their access was restricted by the author. In addition, 19 theses were excluded from the study because they were not related to the subject.

Document analysis method was used to collect data. In this method, it is aimed to analyze the written materials that give information about the research topic (Yıldırım \& Şimşek, 2011). Thus, the previously mentioned 88 thesis studies were transferred to the computer environment in pdf. format from the website of the National Thesis Center of the Council of Higher Education. PRISMA (Preferred Reporting Elements for Systematic Reviews and Meta-Analyses) was guided in the collection and analysis of data (Moher et al., 2009). The diagram of the data collection process is given below.

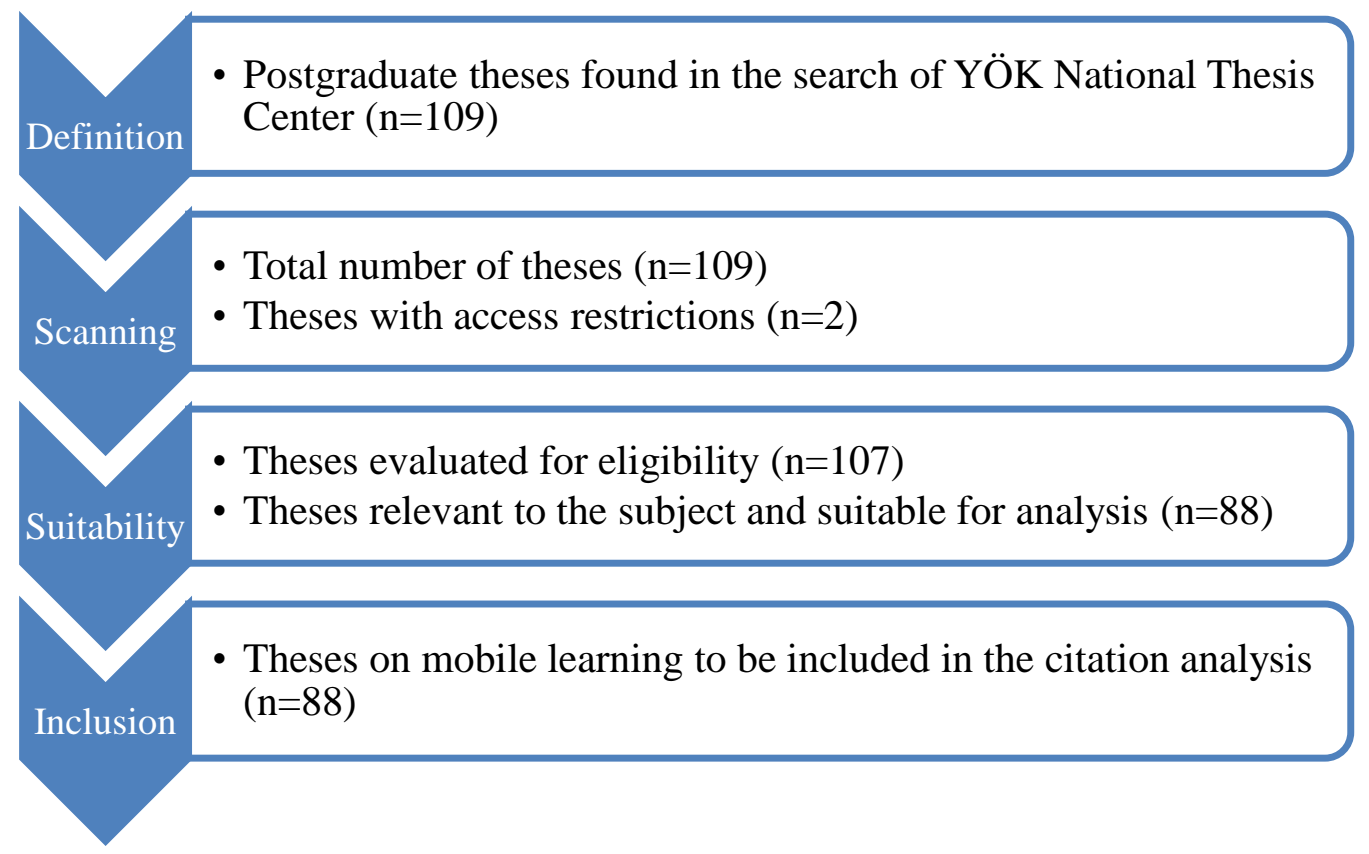

Figure 1. Diagram of data collection

The information about the theses obtained was manually entered into the Microsoft Excel program by the researchers. Each source cited in the theses has been transferred to the Excel program by writing a source on each line. The data obtained from 88 theses were evaluated after the control process. In the citation analysis in the research, theses were examined in two categories as master's and doctorate. Citations made in theses are categorized as book, article, thesis, other (paper, report, etc.) and e-resource (web). Findings were prepared by producing tables with the obtained data. In the Findings section the distribution of graduate theses by year and type, the distribution of the number of pages and citations, the titles of the advisors, the distribution of the advisors, the distribution according to the reference types; the most cited journals, books, authors in the master's theses; The most frequently cited journals and authors in doctoral theses are respectively presented.

In Rank to ensure validity and reliability in scientific research, to report the data in detail and to explain how the results are met, it is important for the researcher to approach the subject impartially (Yıldırım \& Şimşek, 2011). In Rank to establish the validity and reliability of the research, first of all, detailed information about the data selection and processing process was 
tried to be given. It is aimed to allow a second review by storing the examined theses. In the findings, the data are presented directly in the tables. Journals, books and authors were processed by checking from international search engines (Google Scholar) and databases (Web of Science, Scopus, EBSCO, ProQuest, Semantic Scholar). The processed data were checked again by the researchers three weeks later. Thus, the findings were illustrated in their final form.

\section{Findings}

\subsection{Distribution of theses by year and type}

The distribution of postgraduate theses on mobile learning by year and type are given in Table 1. These data were considered important in terms of showing the interest in the subject over the years.

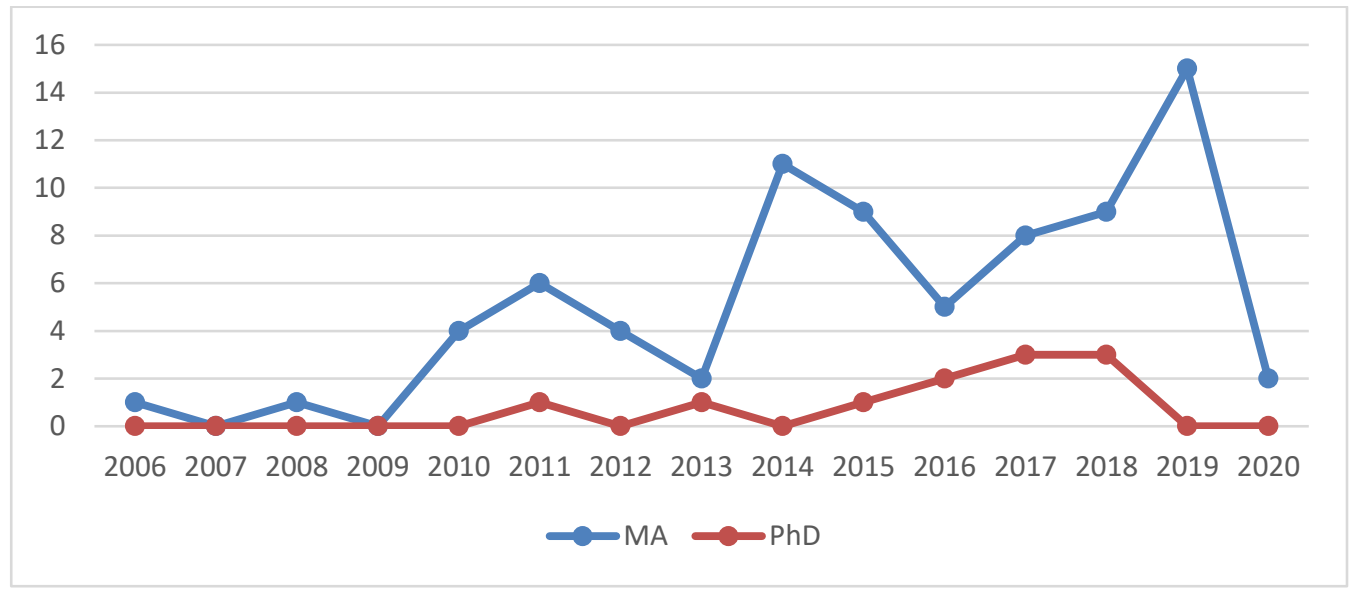

Figure 2. Distribution of theses by years

When Figure 2 is examined, it is seen that the theses about mobile learning started in 2006. A total of 88 theses, including 77 master's and 11 doctoral theses, were submitted on the subject. 1 master's degree in 2006; 1 master's degree in 2008; 4 master's degrees in 2010; In 2011, 6 master's degrees, 1 doctorate; 4 master's degrees in 2012; 2 master's degrees, 1 doctorate in 2013; 11 master's degrees in 2014; In 2015, 9 master's degrees, 1 doctorate; 5 master's degrees, 2 doctorate degrees in 2016; 8 master's degrees, 3 doctorate degrees in 2017; In 2018, 9 masters, 3 doctorate; 15 master's degrees in 2019; In 2020, 2 master's theses were submitted. While the least thesis was submitted in 2006 and 2007, the most theses were submitted in 2019.

\subsection{The distribution of the page and citation of theses}

The distribution of the number of pages and citations of the examined postgraduate theses is presented in Table 1. In this way, it is aimed to reach the averages of pages and resources contained in the theses and to compare them according to the type of thesis.

Table 1. Distribution of pages and citations

\begin{tabular}{|c|c|c|c|c|c|}
\hline \multirow{2}{*}{ Thesis Type } & \multirow{2}{*}{$\begin{array}{l}\text { Number of } \\
\text { Theses }\end{array}$} & \multicolumn{2}{|c|}{ Number of pages } & \multicolumn{2}{|c|}{ Number of Citations } \\
\hline & & $\mathrm{n}$ & Average & $\mathrm{n}$ & Average \\
\hline MA & 77 & 8,388 & 108.93 & 7,660 & 99.48 \\
\hline $\mathrm{PhD}$ & 11 & 2,254 & 204.90 & 1,873 & 170.27 \\
\hline Total & 88 & 1,0642 & 120.93 & 9,533 & 108.32 \\
\hline
\end{tabular}


B. Karagöz \& İ. Şeref - Intellectual Structure of Mobile Learning Field: Bibliometric Evidence from ...

The examination of Table 1 illustrates that the total number of pages of master's theses is 8,388 , and the total number of pages of doctoral theses is 2,254 . It is noteworthy that the average number of pages is 108 pages for master's theses and 204 pages for doctoral theses. While the total number of citations of master's theses is 7,660, the average is 99. Besides, the number of citations of doctoral theses is 1,873 , the average is 170 .

\subsection{Titles of thesis advisors}

Information on the distribution of the titles of the advisors is given in Table 2. Graduate theses, prepared under the consultancy of field experts, are the product of a process involving the advisor and the student. In this respect, the expertise of the consultants and their experience in the field are important for the students. For this reason, it was considered important to determine the supervisors and their titles who directed the thesis.

Table 2. Distribution of titles of consultants

\begin{tabular}{|c|c|c|c|c|c|}
\hline MA & & & $\mathrm{PhD}$ & & \\
\hline Title & $\mathrm{n}$ & $\%$ & Title & $\mathrm{n}$ & $\%$ \\
\hline $\begin{array}{l}\text { Assistant } \\
\text { Professor }\end{array}$ & 35 & 45.45 & $\begin{array}{l}\text { Assistant } \\
\text { Professor }\end{array}$ & 3 & 27.27 \\
\hline $\begin{array}{l}\text { Associate } \\
\text { Professor }\end{array}$ & 27 & 35.06 & $\begin{array}{l}\text { Associate } \\
\text { Professor }\end{array}$ & 4 & 36.36 \\
\hline Professor & 15 & 19.48 & Professor & 4 & 36.36 \\
\hline
\end{tabular}

The titles of the thesis advisors are given in Table 2. Accordingly, the advisors of $45 \%$ of the master's theses were Assistant professors, the advisors of 35\% of them were Associate professors and the advisors of $19 \%$ of master's theses were Professors. The advisors of $27 \%$ of doctoral theses were Assistant professors and $36 \%$ of their advisors were Professors.

\subsection{Distribution by type of source cited in theses}

Distribution data according to the types of sources cited in the theses are given in Table 3. Many types of sources related to the subject examined in scientific studies can be referred to. In this part of the study, the types of sources cited in the theses on the subject were tried to be determined.

Table 3. Distribution by type of source cited

\begin{tabular}{|c|c|c|c|c|c|c|}
\hline \multirow{2}{*}{$\begin{array}{l}\text { Type of } \\
\text { Publication } \\
\text { Cited }\end{array}$} & \multicolumn{2}{|l|}{ MA } & \multicolumn{2}{|l|}{ PhD } & \multicolumn{2}{|l|}{ Total } \\
\hline & $\mathrm{n}$ & $\%$ & $\mathrm{n}$ & $\%$ & $\mathrm{n}$ & $\%$ \\
\hline Book & 1,563 & 20.40 & 523 & 27.92 & 2,086 & 21.88 \\
\hline Article & 3,301 & 43.09 & 937 & 50.02 & 4,238 & 44.45 \\
\hline Thesis & 687 & 8.96 & 137 & $7 \cdot 31$ & 824 & 8.64 \\
\hline E-Resource & 933 & 12.18 & 142 & $7 \cdot 58$ & 1,075 & 11.27 \\
\hline Other & 1,176 & $15 \cdot 35$ & 134 & 7.15 & 1,310 & 13.74 \\
\hline Total & 7,660 & 100 & 1,873 & 100 & 9,533 & 100 \\
\hline
\end{tabular}

Note. E-Source: Web resources, Other: Paper, Report, etc. 
When Table 3 is examined, the most common sources in the master's theses are article-type sources $(n=3,301)$, It is seen that references are made to books in the second place $(n=1,563)$, other types of resources $(n=1,176)$ in the third place, e-resources in the fourth place $(n=933)$, and thesis type resources $(n=687)$ at least. In the doctoral theses, the most cited sources were article type $(n=937)$, second place was book type resources $(n=523)$, third place was eresource type resources $(n=142)$, fourth place was thesis type resource $(n=137)$, the least number of citations was made to other types of sources $(n=134)$. When all postgraduate theses are evaluated together, the most common sources are article type $(n=4,238)$, book type resources $(n=2,086)$, other types of resources $(n=1,310)$, fourth e-resource type $(n=1,075)$, and it was determined that at least thesis type sources $(n=824)$ were cited.

\subsection{Journals most cited in master's theses}

In Table 4, the most frequently cited peer-reviewed academic journals in master's theses are listed by index, number of citations and impact factor information. Thus, the journals in which the sources of the article type used in the theses are included were examined. The index information of these journals is very important. Although there are many directories today, some directories come to the fore due to various reasons such as the number of citations, publication quality, and process professionalism. For example, directories within the scope of Web of Science are in the foreground for various reasons (Asan, 2017). In addition, impact factors are considered as an indicator of the interest in the studies in those journals. In other words, the examination of the journals in which the cited articles are published will present which quality and type (national, international) journals are followed in theses related to mobile learning.

Table 4. Journals most frequently cited in master's theses

\begin{tabular}{|c|c|c|c|c|c|}
\hline Rank & Journal Name & Index & $\begin{array}{l}\text { Number } \\
\text { of } \\
\text { Citations }\end{array}$ & $\begin{array}{l}\text { TR } \\
\text { Index } \\
\text { Citation } \\
\end{array}$ & $\begin{array}{l}\text { Impact } \\
\text { Factor }\end{array}$ \\
\hline 1 & Computers \& Education & SSCI & 216 & - & 5.296 \\
\hline 2 & $\begin{array}{l}\text { Turkish Online Journal of Educational } \\
\text { Technology (TOJET) }\end{array}$ & ERIC & 130 & - & - \\
\hline 3 & British Journal of Educational Technology & SSCI & 94 & - & 2.951 \\
\hline 4 & Procedia - Social and Behavioral Sciences & $\begin{array}{l}\text { closed in } \\
2018\end{array}$ & 93 & - & - \\
\hline 5 & Journal of Computer Assisted Learning & SSCI & 75 & - & 2.126 \\
\hline 6 & $\begin{array}{l}\text { The International Review of Research in Open } \\
\text { and Distributed Learning } \\
\text { ReCALL (The Journal of the European }\end{array}$ & SSCI & 47 & - & 0.734 \\
\hline 7 & $\begin{array}{l}\text { Association for Computer Assisted Language } \\
\text { Learning) }\end{array}$ & SSCI & 46 & - & 1.842 \\
\hline 8 & Educational Technology \& Society & SSCI & 45 & - & 2.086 \\
\hline 9 & Computers in Human Behavior & SSCI & 43 & - & 5.003 \\
\hline 10 & Hacettepe Üniversitesi Ĕ̆itim Fakültesi Dergisi & $\begin{array}{l}\text { ESCI, TR } \\
\text { DİZIN }\end{array}$ & 39 & 8,607 & - \\
\hline
\end{tabular}

Note: Procedia - Social and Behavioral Sciences: It is an open access collection of conference proceedings published between 2009 and 2018 on basic social and behavioral sciences. Eduacuse Quarterly: The journal was closed in 2012 and it was stated by the publisher that Educause Review will include its issues from that year onwards.

When Table 4 is examined, Computers and Education $(\mathrm{n}=216)$, Turkish Online Journal of Educational Technology (TOJET) (n=130), British Journal of Educational Technology $(\mathrm{n}=94)$ are in the first three rows of the journals in which the articles in the type of articles cited in the master's theses are published. Computers \& Education and British Journal of Educational Technology are scanned in SSCI and Turkish Online Journal of Educational Technology is 
B. Karagöz \& İ. Şeref - Intellectual Structure of Mobile Learning Field: Bibliometric Evidence from ...

scanned in ERIC. Of the top 10 most cited journals, 7 are indexed in SSCI, 1 in ERIC, and 1 in both ESCI and TR INDEX. The publication life of 1 journal was terminated.

\subsection{Most cited books in master's theses}

In Table 5, the most cited books and book chapters in master's theses are indicated by the author, the number of citations and the Google Scholar citation number of the book. Books have a vital function in the preservation and dissemination of science and culture (Dalkıran, 2013). As can be seen in the types of sources cited in the theses prepared on mobile learning, sources such as books have been used quite a lot. Determining the most cited books and determining their Google Scholar citation numbers will reveal which types of (national, international) books on the subject are popular.

Table 5. Most cited books in master's theses

\begin{tabular}{|c|c|c|c|}
\hline Rank & Book-Book Chapter & Number of Citations & GS Citation \\
\hline 1 & $\begin{array}{l}\text { Kukulska-Hulme, A., \& Traxler, J. (Ed.) (2007). } \\
\text { Mobile learning: a handbook for educators and } \\
\text { trainers. London: Routledge. }\end{array}$ & 21 & 1,228 \\
\hline 2 & $\begin{array}{l}\text { Karasar, N. (2011). Bilimsel araşttrma yöntemi. } \\
\text { Ankara: Nobel. }\end{array}$ & 20 & 17,008 \\
\hline 3 & $\begin{array}{l}\text { Yıldırım A., \& Şimşek H. (2008). Sosyal bilimlerde } \\
\text { araştırma yöntemleri. Ankara: Seçkin Yayıncllk. }\end{array}$ & 20 & 22,713 \\
\hline 4 & $\begin{array}{l}\text { Alkan, C. (2005). Eğitim teknolojisi. Ankara: Anı } \\
\text { Yayncıllk. } \\
\text { Koole, M. L. (2009). A model for framing mobile }\end{array}$ & 18 & 944 \\
\hline 5 & $\begin{array}{l}\text { learning. In M. Ally (Ed.), Mobile learning: } \\
\text { Transforming the delivery of education and } \\
\text { training. Edmonton: AU Press. }\end{array}$ & 10 & 684 \\
\hline 6 & $\begin{array}{l}\text { Ally, M. (2009). Mobile learning: Transforming } \\
\text { the delivery of education and training. } \\
\text { Edmonton: Athabasca University Press. } \\
\text { Crompton, H. (2013). A Historical overview of m- } \\
\text { learning: Toward learner-centered education. In Z. }\end{array}$ & 8 & 1,032 \\
\hline 7 & $\begin{array}{l}\text { L. Berge \& L. Y. Muilenburg (Eds.), Handbook of } \\
\text { mobile learning (pp. 3-15). New York, USA: } \\
\text { Routledge Taylor and Francis Group. }\end{array}$ & 7 & \\
\hline 8 & $\begin{array}{l}\text { Sharples, M., Amedillo-Sanchez, I., Milrad, M., \& } \\
\text { Vavoula, G. (2009). Mobile learning: Small } \\
\text { devices, big issues. In Balacheff, S. Ludvigsen, T., } \\
\text { D. Jongand, \& S. Barnes (Eds.), Technology } \\
\text { enhanced learning (pp. 233-249). California: } \\
\text { SAGE Publications. }\end{array}$ & 7 & 949 \\
\hline 9 & $\begin{array}{l}\text { Kaya, Z. (2002). Uzaktan eğitim. Ankara: Pegem- } \\
\text { A Yayıncılık. }\end{array}$ & 7 & 353 \\
\hline 10 & $\begin{array}{l}\text { Woodill, G. (2011). The mobile learning edge. } \\
\text { USA: McGraw-Hill Companies. }\end{array}$ & 7 & 213 \\
\hline
\end{tabular}

In Table 5, the most cited book/book chapters in master's theses are listed. Accordingly, Agnes Kukulska-Hulme and John Traxler's Mobile Learning: A Hand book for Educators and Trainers (21) took the first place. In the second and third place are research methods and books. In the fourth place, Cevat Alkan's book Educational Technology (18) was cited. In fifth place is the book chapter A Model for Framing Mobile Learning (10) by Marguerite L. Koole. 


\subsection{Most cited authors in master's theses}

In Table 6, the most cited authors in their master's theses are presented together with the citation numbers in the theses and the citation numbers in their Google Scholar profiles. Determining the most cited authors in the theses about mobile learning is considered important as it will show which researchers are followed in this field.

Table 6. Authors most cited in master's theses

\begin{tabular}{llcc}
\hline Rank & Writer & $\begin{array}{c}\text { Number of } \\
\text { Citations }\end{array}$ & $\begin{array}{c}\text { Google } \\
\text { Scholar Citation }\end{array}$ \\
\hline 1 & Mike Sharples & 114 & 22,157 \\
2 & Giasemi Vavoula & 87 & 9,477 \\
3 & John Traxler & 86 & 8,399 \\
4 & Agnes Kukulska-Hulme & 80 & 12,072 \\
5 & Sirin Karadeniz & 45 & 13,814 \\
6 & Nilgün Özdamar-Keskin & 41 & - \\
7 & Jill Attewell & 36 & - \\
8 & Josie Taylor & 35 & - \\
9 & Şener Büyüköztürk & 33 & 39,496 \\
10 & Birol Gülnar & 33 & 1,931 \\
\hline
\end{tabular}

Note. The information about the authors in the blank lines could not be found.

When Table 6 is examined, the first four of the most cited authors in master's theses are Mike Sharples $(n=114)$, Giasemi Vavoula $(n=87)$, John Traxler $(n=86)$, Agnes Kukulska-Hulme $(\mathrm{n}=80)$. Mike Sharples, who is in the first place, is an Emeritus Professor of Educational Technology at The Open University, Institute of Educational Technology in England. As can be understood from the author's post, his area of expertise is educational technologies. Giasemi Vavoula, in second place, works at the University of Leicester in England. The author's Google Scholar profile includes technology-enhanced learning and mobile learning tags. Third place author, John Traxler, has been the world's first professor of mobile learning since September 2009 and is currently a professor of digital learning at the University of Wolverhampton Institute of Education, UK. The fourth ranked author, Agnes Kukulska-Hulme, is Professor of Learning Technology and Communication at the Institute of Educational Technology, UK. The first Turkish writer in the list is Sirin Karadeniz. The author continues her academic life with the title of Professor Doctor in the Department of Computer and Instructional Technologies Education at Bahçeşehir University, Faculty of Educational Sciences.

\subsection{Journals most cited in doctoral theses}

In Table 7, the most cited peer-reviewed academic journals in doctoral theses are given together with the index, number of citations and impact factor information.

Table 7. Journals most cited in doctoral theses

\begin{tabular}{llllll}
\hline Rank & Journal Name & Index & $\begin{array}{l}\text { Number of } \\
\text { Citations }\end{array}$ & $\begin{array}{l}\text { TR Index } \\
\text { Citation }\end{array}$ & $\begin{array}{l}\text { Impact } \\
\text { Factor }\end{array}$ \\
\hline 1 & Computers \& Education & SSCI & 47 & - & 5.296 \\
2 & $\begin{array}{l}\text { British Journal of Educational } \\
\text { Technology }\end{array}$ & SSCI & 31 & - & 2.951 \\
\multirow{2}{*}{$\begin{array}{l}\text { International Review of Research } \\
\text { in Open and Distributed Learning }\end{array}$} & SSCI & 24 & - & 0.734 \\
4 & $\begin{array}{l}\text { Procedia - Social and Behavioral } \\
\text { Sciences }\end{array}$ & Terminated in & 24 & - & - \\
\multirow{2}{*}{5} & $\begin{array}{l}\text { Journal of Computer Assisted } \\
\text { Learning }\end{array}$ & SSCI & 23 & - & 2.126
\end{tabular}


B. Karagöz \& İ. Şeref - Intellectual Structure of Mobile Learning Field: Bibliometric Evidence from ...

\begin{tabular}{|c|c|c|c|c|c|}
\hline 6 & $\begin{array}{l}\text { Turkish Online Journal of } \\
\text { Educational Technology (TOJET) }\end{array}$ & ERIC & 20 & - & - \\
\hline 7 & Computers in Human Behaviour & SSCI & 17 & - & 5.003 \\
\hline 8 & Educational Technology \& Society & SSCI & 13 & - & 2.086 \\
\hline 9 & Language Learning & SSCI & 10 & - & 3.408 \\
\hline 10 & Language Learning \& Technology & SSCI & 8 & - & 2.473 \\
\hline
\end{tabular}

When Table 7 is examined, the first four of the journals in which the articles in the type of articles cited in doctoral theses are published are Computers \& Education $(\mathrm{n}=47)$, British Journal of Educational Technology $(\mathrm{n}=31)$, International Review of Research in Open and Distributed Learning (n=24), Procedia - Social and Behavioral Sciences $(n=24)$ are included. Computers \& Education, British Journal of Educational Technology, and International Review of Research in Open and Distributed Learning are indexed in SSCI. 8 of the top 10 most cited journals are indexed in SSCI and 1 in ERIC indexes. The publication life of 1 journal was terminated.

\subsection{Most cited books in doctoral theses}

In Table 8, the most cited books and book chapters in doctoral theses are indicated by the author, the number of citations and the Google Scholar citation number of the book.

Table 8. The most cited books in doctoral theses

\begin{tabular}{|c|c|c|c|}
\hline Rank & Book-Book Chapter & $\begin{array}{l}\text { Number of } \\
\text { Citations }\end{array}$ & $\begin{array}{l}\text { Google Scholar } \\
\text { Citation }\end{array}$ \\
\hline 1 & $\begin{array}{l}\text { Ally, M. (2009). Mobile Learning: Transforming the delivery of } \\
\text { Education and Training. Athabasca: Athabasca University Press. } \\
\text { Naismith, L., Lonsdale, P., Vavoula, G., \& Sharples, M. (2004). }\end{array}$ & 7 & 1,030 \\
\hline 2 & $\begin{array}{l}\text { Literature review in mobile technologies and learning. Bristol: } \\
\text { NESTA Future Lab. }\end{array}$ & 5 & 1,485 \\
\hline 3 & $\begin{array}{l}\text { Kukulska-Hulme, A., \& Traxler, J. (2005). Mobile learning: A } \\
\text { handbook for educators and trainers. London: Routledge. }\end{array}$ & 4 & 1,225 \\
\hline 4 & $\begin{array}{l}\text { Nation, I. S. P. (2001). Learning vocabulary in another language. } \\
\text { Cambridge: Cambridge University Press. }\end{array}$ & 4 & 11,037 \\
\hline 5 & $\begin{array}{l}\text { Creswell, J. W. (2008). Educational research: Planning, conducting } \\
\text { and evaluating quantitative and qualitative research. Boston: } \\
\text { International Pearson Merril Prentice Hall. }\end{array}$ & 4 & 52,297 \\
\hline 6 & $\begin{array}{l}\text { Ylldırım, A., \& Simşsek, H. (2008). Sosyal bilimlerde nitel araştırma } \\
\text { yöntemleri. Ankara: Seçkin Yayıncılı. }\end{array}$ & 4 & 22,644 \\
\hline 7 & $\begin{array}{l}\text { Creswell, J. W. (2009). Research design: Qualitative, quantitative, } \\
\text { and mixed methods approaches ( }{ }^{\text {rd }} \text { ed.). USA: Sage Publication s. }\end{array}$ & 3 & 152,875 \\
\hline 8 & $\begin{array}{l}\text { Büyüköztürk, S. (2012). Sosyal bilimler için veri analizi el kitabı. } \\
\text { Ankara: Pegem Akademi. } \\
\text { Büyüköztürk, Ș., Çakmak, E. K., Akgün, Ö. E., Karadeniz, S.., \& }\end{array}$ & 3 & 11,695 \\
\hline 9 & $\begin{array}{l}\text { Demirel, F. (2012). Bilimsel araştırma yöntemleri. Ankara: Pegem } \\
\text { Akademi. }\end{array}$ & 3 & 9,051 \\
\hline 10 & $\begin{array}{l}\text { Bogdan, R. C. \&Biklen, S. K. (1998). Qualitative research for } \\
\text { education and Introduction to theory and practice. Boston: Allyn } \\
\text { \&Bacon. }\end{array}$ & 3 & 42,522 \\
\hline
\end{tabular}

In Table 8, the top 10 sources in the type of book/book chapter most cited in doctoral theses are listed. According to the table, Mohamed Ally's Mobile Learning: Transforming the Delivery of Education and Training $(\mathrm{n}=7)$ is in the first place. In second place is Literature Review in Mobile Technologies and Learning $(\mathrm{n}=5)$ by Laura Naismith, Peter Lonsdale, Giasemi Vavoula, Mike Sharples. 6 of these books are studies on scientific research methods. 4 of them are books that can be said to be in the field of education and educational technology. 3 of the books/book chapters were produced by Turkish and 7 of them were produced by foreign academicians. 


\subsection{Most cited authors in doctoral theses}

Table 9 presents data on the most cited authors in doctoral theses, the number of citations in theses, and the number of Google Scholar citations.

Table 9. Authors most cited in doctoral dissertations

\begin{tabular}{llll}
\hline Rank & Writer & Number of Citations & GS Citation \\
\hline 1 & Mike Sharples & 39 & 22,157 \\
2 & Giasemi Vavoula & 34 & 9,477 \\
3 & John Traxler & 22 & 8,399 \\
4 & Agnes Kukulska-Hulme & 19 & 12,072 \\
5 & Josie Taylor & 16 & - \\
6 & John W. Creswell & 13 & - \\
7 & Jan Herrington & 12 & 15,093 \\
8 & Mohamed Ally & 10 & - \\
9 & Lev S. Vygotsky & 10 & - \\
10 & Claire O'Malley & 9 & - \\
\hline
\end{tabular}

When Table 9 is examined, it is seen that the first four of the most cited authors in master's theses are Mike Sharples $(n=39)$, Giasemi Vavoula $(n=34)$, John Traxler $(n=22)$, Agnes Kukulska-Hulme $(n=19)$. The most cited authors in the master's thesis studies and the first four most cited authors in the doctoral thesis studies are the same. In addition, when the other parts of the lists are compared, it can be said that the most cited authors in master's and doctoral theses are generally similar.

\section{Discussion and conclusion}

In the present research, it was tried to analyze the citations in the bibliography of the postgraduate theses regarding mobile learning. Thus, in addition to the distribution of the postgraduate theses by year and genre, the number of pages and citations, the titles of their advisors, the names of their advisors, the types of sources they cited, the most cited journals in master's theses, the most cited books in master's theses, and the most cited books in master's theses, the authors, the most cited journals in doctoral theses, the most cited books in doctoral theses, and the most cited authors in doctoral theses were examined.

A total of 88 postgraduate theses, including 77 master's and 11 doctoral theses, were prepared in Turkey between the years 2006-2020 on mobile learning. The number of theses prepared on the subject has started to increase since 2014. In the Household Information Technologies (IT) Usage Survey (TUIK, 2020), it is stated that $86.9 \%$ of the households provide internet access with a mobile broadband connection. As can be seen here, mobile device internet usage has become quite high. Accordingly, it can be stated that the use of mobile devices has increased with the development of technology. It can be seen that the number of studies conducted in this study has increased as the present day. Accordingly, it can be said that thesis researches on the subject show a tendency related to daily life. In the researches, it is stated that the number of article studies on mobile learning has increased as the day approaches (Göksu, 2021; Sobral, 2020). However, two theses were found in 2020. The reason for this situation can be shown as COVID-19, which has affected the world in the last year and caused the disruption of scientific activities. It is predicted that the number of studies on mobile learning will increase in the coming years.

When the prepared theses were evaluated in terms of the average number of pages, the number of pages was found to be 108 in the master's theses and 204 in the doctoral theses. Considering the average number of citations, it has been determined that the average number of citations is 99 in master's theses and 170 in doctoral theses. Studies by Al and Tonta (2004), Şeref 
and Karagöz (2020), Kushkowski, Parsons and Wiese (2003), also stated that doctoral theses have higher number of pages and citations. This study is similar to other studies. This result can be explained by the fact that doctoral education is a more detailed process. Because the doctorate program, which is the highest education level, can be considered as a situation that is expected to be completed with a detailed thesis study.

The titles of the advisors of the examined theses are mostly Dr. Instructor Although the number of members is similar in all titles at the doctoral level, Assoc. Dr. and Prof. Dr. title is more common. It can be considered as an expected situation that the titles of the advisors of the theses prepared in a higher education level are also higher. In addition, it can be said that the advisors of the theses vary. Because there are six faculty members who have two or more advisors on mobile learning.

It has been determined that the most article type sources are used in postgraduate theses. This is followed by sources in the types of books, other (reports, papers, etc.), e-resources (web), thesis, respectively. In the study conducted by Şerefoğlu-Henkoğlu, Mizanalı and Barutçu (2019), in which the citations of the theses in the field of management information systems were examined, it was found that $52 \%$ of the citations were made to the articles. The fewest references were made to sources in the thesis type and other types. In the citation analysis study of the articles on educational sciences and teacher training in Turkey by Karadağ et al. (2017), it was determined that the most used sources were the articles published in scientific journals. In the study by Xu, Yang, and Zhu (2018), in which articles on mobile learning in the Web of Science database were examined bibliometrically, it was stated that all of the top ten most cited works were in the article type. The increase in the number of academic journals has led to an increase in the number of academic studies published in these journals. It can be said that as a result of the increasing number of online databases and the ease of access to academic articles, citations to journals have increased (Karadağ, et al., 2019).

Articles published in Computers \& Education, Turkish Online Journal of Educational Technology, British Journal of Educational Technology were mostly cited in master's theses. In the doctoral theses, the most references were made to the articles in the journals Computers \& Education, British Journal of Educational Technology, International Review of Research in Open and Distributed Learning, Procedia-Social and Behavioral Sciences. The most cited journals are generally indexed in the Social Sciences Citation Index. This situation shows that international literature is followed in postgraduate theses on mobile learning. The fact that mobile learning is a global and up-to-date field has created an effect that makes journals scanned in respected international indexes want to include this subject. Göksu (2021) stated that the most active journals about mobile learning are Computers \& Education, British Journal of Educational Technology and Educational Technology \& Society. It can be said that the journals used in the theses about mobile learning in Turkey show similarities with the international literature. In addition, it is seen that the subject areas of the journals are related to education, technology and computers.

The first three of the most cited sources in the master's these are the following books: Mobile Learning: A Handbook for Educators and Trainers (Agnes Kukulska-Hulme and John Traxler), Scientific Research Methods (Niyazi Karasar), Research Methods in Social Sciences. (Ali Ylldırım and Hasan Şimşek). In doctoral theses, Mohamed Ally's book Mobile Learning: Transforming the Delivery of Education and Training is in the first place, followed by the book Literature Review in Mobile Technologies and Learning written by Laura Naismith, Peter Lonsdale, Giasemi Vavoula, Mike Sharples. When we look at the most used books, it is seen that there are scientific research books as well as books on mobile learning. In the citation analysis study of articles on educational sciences and teacher training in Turkey conducted by Karadağ, there are books on scientific research methods in the first three of the book-type resources. Although it is not related to the field, the reason for the frequent use of such books can be 
considered as the fact that these books guide the authors in the research process. Because graduate students may encounter problems such as choosing the wrong method or technique or inadequacy in scientific ethics while preparing their thesis (Büyüköztürk et al., 2010). In this respect, it can be said that scientific research methods books are very important in carrying out the research process in line with a plan.

Mike Sharples, Giasemi Vavoula, John Traxler, Agnes Kukulska-Hulme constitute the first four of the most cited authors in master's and doctoral theses on mobile learning. When the institutions where these authors work are examined, it is seen that all of them work in England. In the study of Göksu (2021), in which she examined the articles on mobile learning bibliometrically, it was stated that England is among the most effective countries in mobile learning. In the mobile learning trend study conducted by Bhardwai and Jain (2015), England was among the countries that produce the most publications. In this study, the first four authors most cited in master's and doctoral theses are from the UK. This shows that this country has studies that can be considered as qualified in the field of mobile learning. Lai (2020) in his study on trends in mobile learning found that Mike Sharples was the most prolific writer between 2003-07, and Gwen-JenHwang's first and second Sharples's in all times found that. In the study by Xu, Yang, and Zhu (2018), in which articles on mobile learning in the Web of Science database were analyzed bibliometrically, Mike Sharples was identified as the third most cited author. In the so-called research, the most cited author in master's and doctoral theses was Mike Sharples. The author is Professor Emeritus at The Open University UK. It can be said that Sharples was one of the first pioneers in the field of mobile learning, which is already a current field. In addition, Hwang, who is seen as the most prolific writer of all time in Lai's (2020) study, ranked high in the citations made in the theses on mobile learning in Turkey.

The research is limited to 88 National Thesis Center of the Council of Higher Education. For this reason, it is necessity to evaluate the results obtained from the research according to this limitation. When the scope of the research is expanded, different results can be obtained. A comparative examination of the international thesis studies on mobile learning and the articles in Turkey and international journals can provide a broader view on the situation of the literature in Turkey.

\section{Acknowledgements}

This research did not receive any specific grant from funding agencies in the public commercial, or not-for-profit sectors.

The authors declare no competing interests.

\section{References}

Al, U., \& Tonta, Y. (2004). Atıf Analizi: Hacettepe Üniversitesi Kütüphanecilik Bölümü tezlerinde atıf yapılan kaynaklar. Bilgi Dünyası, 5(1), 19-47.

Altunçekiç, A. (2020). 2010-2020 yılları arasında mobil öğrenme çalışmalarının içerik analizy öntemiile değerlendirilmesi: Türkiye örneği. Gazi Üniversitesi Gazi Eğitim Fakültesi Dergisi, $40(3), 1087-1104$.

Asan, A. (2017). Uluslararası bilimsel dergi indeksleri, önemleri ve Türkiye kaynaklı dergilerin durumu: Bölüm 1: Bilimsel dergi indeksleri. Acta Medica Alanya, 1(1), 33-42. 
B. Karagöz \& İ. Şeref - Intellectual Structure of Mobile Learning Field: Bibliometric Evidence from ...

Aydoğdu, H. (2019). Mobil öğrenmeile ilgili araştırmaların eğilimleri: bir içerik analizi. Yayımlanmamış yüksek lisans tezi, Fırat Üniversitesi, Eğitim Bilimleri Enstitüsü, Elazı̆̆.

Becker, D. A., \& Chiware, E. R. (2015). Citation analysis of masters' theses and doctoral dissertations: Balancing library collections with students' research information needs. The Journal of Academic Librarianship, 41(5), 613-620.

Bhardwaj, R. K., \& Jain, P. K. (2015). Research trends in mobile learning: A global perspective, Collnet Journal of Scientometrics and Information Management, 9(2), 205-224. https://doi.org/10.1080/09737766.2015.1069960

Büyüköztürk, Ş., Kılıç-Çakmak, E., Akgün, Ö. E., Karadeniz, Ş., \& Demirel, F. (2010). Bilimsel araştırma yöntemleri (6. baskı). Ankara: PegemYayınları.

Çelik, A. (2012). Yabancı dil öğreniminde karekod destekli mobil öğrenme ortamını aktif sözcük öğrenimine etkisi ve öğrenci görüşleri: Mobil sözlük örneği. Yayımlanmamış yüksek lisans tezi, Gazi Üniversitesi Ĕgitim Bilimleri Enstitüsü, Ankara.

Cheung, A. C., \& Slavin, R. E. (2012). How features of educational technology applications affect student reading outcomes: A meta-analysis. Educational Research Review, 7(3), 198-215.

Chu, H. C., Hwang, G. J., Tsai, C. C., \& Tseng, J. C. R. (2010). A two-tier test approach to developing locationaware mobile learning systems for natural science course. Computers \& Education, 55(4), 1618-1627.

Corbeil, J. R., \& Valdes-Corbeil, M. E. (2007). Are you ready for mobile learning? EDUCAUSE Quarterly, $30(2), 48-51$.

Dalkıran, Ö. (2013). Kitabın tarihi. Türk Kütüphaneciliği, 27(1), 201-213.

Dikmen, M., \& Tuncer, M. (2018). Bilgisayar destekli eğitimin öğrencilerin akademik başarıları üzerindeki etkisinin meta-analizi: Son 10 yılda yapılan çalışmaların incelenmesi. Turkish Journal of Computer and Mathematics Education, 9(1), 97-121.

Dinçer, S. (2015). Türkiye'de yapılan bilgisayar destekli öğretimin öğrenci başarısına etkisi ve diğer ülkelerle karşılaştırılması: Bir meta-analiz çalışması. Journal of Turkish Science Education, 12(1), 99118.

Göksu, I. (2021). Bibliometric mapping of mobile learning. Telematics and Informatics, 56, 101491.

Göksu, İ., \& Bolat, Y. İ. (2020). Teknolojİ kullanimi Türkiye'de öğrencilerin akademik başarilarini etkiliyor mu? Bir meta-analiz çalişmasi. Eğitim Teknolojisi Kuram ve Uygulama, 1o(1), 138-176.

Gür, D., \& Bulut-Özek, M. (2021). Mobil öğrenmenin öğrencilerin akademik başarısı, motivasyonu ve tutumları üzerine etkisi: Bir meta analiz çalışması. Trakya Eğitim Dergisi, 11(1), 1-15.

Güzeller, C. O., \& Üstünel, F. (2016). Mobil öğrenmenin öğrenci başarısına etkisi: Bir meta analiz çalışması. Adıyaman Üniversitesi Sosyal Bilimler Enstitüsü Dergisi, (23), 528-561.

Kantaroğlu, T., \& Akbıyı, A. (2017). İşletme Fakültesi ve Eğitim Fakültesi öğrencilerinin mobil öğrenmeye yönelik tutumlarının karşılaştırılması. İşletme Bilimi Dergisi, 5(2), 25-50.

Karadağ, E., Yalçın, M., Çiftçi, K., Danışman, Ş., Sölpük, N., Tosuntaş, Ş., \& Ay, Y. (2017). Türkiye'de eğitim bilimleri ve öğretmen yetiştirme alanındaki bilimsel yayınların atıf analizleri. Bilgi Dünyası, 18(1), 9-28.

Karagöz, B., \& Şeref, İ. (2020). Yazma becerisiyle ilgili makaleler üzerine bir inceleme: Web of Science veri tabanında eğilimler. Ana Dili Ĕ̆itimi Dergisi, 8(1), 67-86.

Kavaklı, A., \& Yakın, İ. (2019). Mobil Öğrenme: 2015-2019 çalışmalarına yönelik bir içerik analizi. Karadeniz Sosyal Bilimler Dergisi, 11(21), 251-268.

Korucu, A. T., \& Biçer, H. (2019). Mobil öğrenme: 2010-2017 çalışmalarına yönelik bir içerik analizi. Trakya Ĕ̆itim Dergisi, 9(1), 32-43. 
Kushkowski, J. D., Parsons, K. A., \& Wiese, W. H. (2003). Master's and doctoral thesis citations: Analysis and trends of a longitudinal study. Libraries and the Academy, 3(3), 459-479.

Lai, C. L. (2020). Trends of mobile learning: A review of the top 100 highly cited papers. British Journal of Educational Technology, 51(3), 721-742.

Moher, D., Liberati, A., Tetzlaff, J., Altman, D. G., \& Prisma Group. (2009). Preferred reporting items for systematic reviews and meta-analyses: the PRISMA statement. PLoS medicine, 6(7), e1000097.

Schmid, R. F., Bernard, R. M., Borokhovski, E., Tamim, R. M., Abrami, P. C., Surkes, M. A., ... \& Woods, J. (2014). The effects of technology use in post-secondary education: A meta-analysis of classroom applications. Computers \& Education, 72, 271-291.

Şeref, İ., \& Karagöz, B. (2020). Citation analysis of graduate theses on teaching of Turkish as a foreign language (1988-2019). Çukurova Üniversitesi Eğitim Fakültesi Dergisi, 49(2), 1145-1183.

Şeylan, F. (2018). Mobil Öğrenmenin Akademik Başarıya Etkisi Üzerine Yapılan Deneysel Çalışmaların Karşılaştırılması. Yayımlanmamış yüksek lisans tezi, Yüzüncü Yıl Üniversitesi, Eğitim Bilimleri Enstitüsü, Van.

Sobral, S. R. (2020). Mobile learning in higher education: A bibliometric review. iJIM, 14(11), 153-170.

Sönmez, N., \& Çapuk, S. (2019). Mobil öğrenmenin akademik başarıya etkisi: bir meta-analiz çalışması. Tarih OkuluDergisi, 12(41), 884-924.

Tanrıverdi, M. (2011). E-öğrenmeye destek amaçh mobil öğrenme uygulaması geliştirme ve etkilerinin incelenmesi. Yayımlanmamış yüksek lisans tezi, Gazi Üniversitesi, Bilişim Enstitüsü, Ankara.

Tomakin, E., \& Yeşilyurt, M. (2013). Bilgisayar destekli yabancı dil öğretim çalışmalarının meta analizi: Türkiye örneği. Yüzüncü Yll Üniversitesi Eğitim Fakültesi Dergisi, 1O(1), 248-263.

TÜİK (2021). Hanehalkı Bilişim Teknolojileri (BT) Kullanım Araştırması. https://data.tuik.gov.tr/Bulten/Index?p=Hanehalki-Bilisim-Teknolojileri-(BT)-KullanimArastirmasi-2020-33679.

Uygun, D., \& Sönmez, A. (2019). Mobil öğrenme üzerine güncel çalışmalar lailgili bir içerik analizi. AU Ad, 5(1), 53-69.

Xu, S., Yang, H. H., \& Zhu, S. (2018, July). Visualizing and understanding the hotspots and trends of mobile learning. In 2018 International Symposium on Educational Technology (ISET) (pp. 255-260). IEEE.

Yıldırım, A., \& Şimşek, H. (2011). Sosyal bilimlerde nitel araştırma yöntemleri. Ankara: Seçkin Yayıncılık.

Yıldırım, N. (2012). Yabancı dil eğitiminde oyun lar aracılı̆̆ıyla mobil öğrenme. Yayımlanmamış yüksek lisans tezi, Frrat Üniversitesi Eğitim Bilimleri Enstitüsü, Elazığ.

Yıldız-Avcı, Z. (2018). Mobil öğrenme araştırma larıve uygulamalarına ilişkin bir meta analiz çalışması. Yayımlanmamış yüksek lisans tezi, Frrat Üniversitesi, Eğitim Bilimleri Enstitüsü, Elazı̆̆. 
B. Karagöz \& İ. Şeref - Intellectual Structure of Mobile Learning Field: Bibliometric Evidence from ... 